\title{
CORRIGENDUM
}

\section{The anti-angiogenic herbal composition Ob-X inhibits adipose tissue growth in obese mice}

M-Y Kim, BY Park, HS Lee, EK Park, JC Hahm, J Lee, Y Hong, S Choi, D Park, H Lee and M Yoon International Journal of Obesity (2010) 34, 1354; doi:10.1038/ijo.2010.68

Correction to: International Journal of Obesity advance online publication, 23 February 2010; doi:10.1038/ijo.2010.13

After the publication of the above article, the authors noticed a major error in Figure 7. The correct figure is reproduced below.

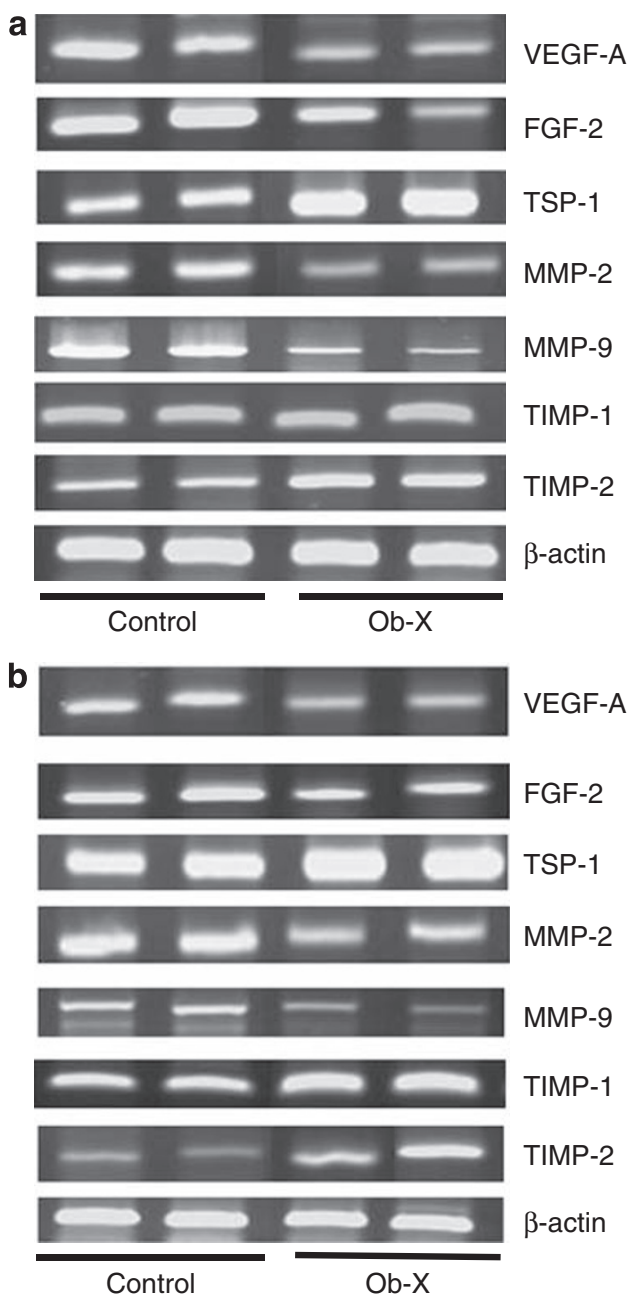

Figure 7
The authors would like to apologize for this mistake. 